\title{
QUEEN'S
UNIVERSITY
BELFAST
}

\section{The Future Study of Terrorism}

English, R. (2016). The Future Study of Terrorism. European Journal of International Security, 1(2), 135-149. https://doi.org/10.1017/eis.2016.6

\section{Published in:}

European Journal of International Security

\section{Document Version:}

Peer reviewed version

\section{Queen's University Belfast - Research Portal:}

Link to publication record in Queen's University Belfast Research Portal

\section{Publisher rights}

(c) 2016 British International Studies Association.

\section{General rights}

Copyright for the publications made accessible via the Queen's University Belfast Research Portal is retained by the author(s) and / or other copyright owners and it is a condition of accessing these publications that users recognise and abide by the legal requirements associated with these rights.

Take down policy

The Research Portal is Queen's institutional repository that provides access to Queen's research output. Every effort has been made to ensure that content in the Research Portal does not infringe any person's rights, or applicable UK laws. If you discover content in the Research Portal that you believe breaches copyright or violates any law, please contact openaccess@qub.ac.uk. 


\title{
The Future Study of Terrorism
}

\author{
Richard English
}

(University of St Andrews)

Abstract

This article reflects on the central problems to be faced over the next fifty years of the academic study of terrorism. It discusses a series of problems that are sometimes raised (regarding definition, the division between Critical Terrorism Studies and Orthodox Terrorism Studies, and the supposed stagnation in contemporary terrorism research), and argues that these present rather limited difficulties, in reality. It then identifies a greater problem, in the form of a five-fold fragmentation of the current field, before offering suggested 
means of addressing in practice these latter, more profound difficulties.

Keywords: terrorism, terrorism studies, political violence

\section{Introduction}

Terrorism and responses to terrorism continue to define politics in deeply significant ways across much of the world; the scholarly and analytical understanding of terrorism therefore represents one of the grandest challenges that we collectively face. This article considers the current state of work on the subject, imagining two fifty-year periods of terrorism research. The first (1965-2015) covers the years between the emergence of serious scholarly interest in the subject ${ }^{1}$ and the moment of this article's composition. The

1 Arguably the greatest of terrorism scholars, Martha Crenshaw, formally began her graduate student research 
second (2015-65) will contain work which we have yet to pursue, within frameworks that are yet to be determined. The central aim of the article is to ask, on the basis of what we know to have been done in the field to date, what the central problems in the future half-century are most likely to be, and how we might best address them in practice.

My intention here is not to summarize the broad findings of the field (something which I have already attempted to do elsewhere). ${ }^{2}$ Rather, my approach will be: first, to identify some issues commonly presented as problematic but which, I argue, in reality represent only comparatively minor difficulties; second, to set out what do indeed seem to me to

into terrorism in 1967 (Martha Crenshaw, Explaining Terrorism: Causes, Processes and Consequences (London: Routledge, 2011), p. ix). For consideration of the early years of the academic study of terrorism (focusing mainly on the USA), see Lisa Stampnitzky, Disciplining Terror: How Experts Invented 'Terrorism' (Cambridge: Cambridge University Press, 2013).

${ }^{2}$ Richard English, 'The Enduring Illusions of Terrorism and Counter-Terrorism', in Richard English (ed.), Illusions of Terrorism and Counter-Terrorism (Oxford: Oxford University Press, 2015). 
be major problems to be faced; and, third, to say something about how best we might collectively and individually face these latter challenges. The overarching goal is to make an admittedly small contribution to what is surely a large and significant process: namely, that of ensuring that our research into, and our understanding of, terrorism during the next fifty years gains strength and sharpness through honest reflection about the problems we face, given what has and what has not been achieved over the past halfcentury. The future study of terrorism will only be at its most fruitful and creative if we are clear about the most important challenges which past research has left to us as a legacy.

First, let's consider some problems which have been identified but which, I argue, should cause us comparatively 
little anxiety. One is the perennial matter of definition. It is very often pointed out that there exists no consensual definition of the word 'terrorism'. It is less often acknowledged that this is a common issue with other social phenomena of political significance (nationalism, revolution, empire, fascism, imperialism, colonialism).

Very valuable contributions continue to be made to the definitional debate. ${ }^{3}$ And it is not, of course, that there exist no problems here. Should we, for example, deploy the term 'terrorism' to apply only to non-state groups, or should we use it for state actors also? (My own approach here is to recognize that states as well as non-state actors practise

3 Alex P. Schmid (ed.), The Routledge Handbook of Terrorism Research (London: Routledge, 2011); Anthony Richards, 'Conceptualizing Terrorism', Studies in Conflict and Terrorism, 37:3 (2014); Paul Wilkinson and Dominic Bryan, 'Is Terrorism Still a Useful Analytical Term or Should it Be Abandoned?', in Richard Jackson and Samuel J. Sinclair (eds), Contemporary Debates on Terrorism (London: Routledge, 2012); Gilbert Ramsay, 'Why Terrorism Can, But Should Not Be Defined', Critical Studies on Terrorism, 8:2 (2015); Anthony Richards, Conceptualizing Terrorism (Oxford: Oxford University Press, 2015). 
terrorism, but that the dynamics and scale respectively involved in the two processes are divergent and therefore difficult to study synoptically.) Again, do we define terrorism so as to include anti-colonial movements? ${ }^{4}$ Yet again, there is the issue of defining particular groups or organizations as terrorist. If Hamas is to be labelled a terrorist organization because (along with its many other, non-terroristic activities) it has practised some acts which we consider terrorism, then should we not say the same of the United States Air Force or the British Army? Even those who admit that states practise terrorism tend to be less prone to defining those states as terrorist states, than they are to label non-state groups as terrorist organizations. And to label an act terroristic is less central to the definitional problem, perhaps, than is the question of whether or not

${ }^{4}$ Thereby involving the issues addressed in: Rory Cormac, Confronting the Colonies: British Intelligence and Counterinsurgency (London: Hurst and Company, 2013); Huw Bennett, Fighting the Mau Mau: The British Army and Counter-Insurgency in the Kenya Emergency (Cambridge: Cambridge University Press, 2013). 
carrying out some terroristic acts means that we label the practising organization a terroristic one.

Despite all this, the truth is that, in addition to nonconsensus being a familiar problem (even in the case of other pejorative terms such as fascism or imperialism), so too there exists much common ground between rival definitions of 'terrorism'. ${ }^{5}$ For many years, it has been perfectly possible for people to recognize and say intelligent things about the contested nature of the word 'terrorism', and then to offer a workable definition within which to produce serious scholarship themselves, without ignoring different people's rival understandings of the word. ${ }^{6}$ The

5 Schmid (2011); Ramsay (2015); Richards (2015), pp. 9, 12, 18-19.

${ }^{6}$ Juliet Lodge (ed.), Terrorism: A Challenge to the State (Oxford: Martin Robertson, 1981), pp. 1-5; Louise Richardson, What Terrorists Want: Understanding the Terrorist Threat (London: John Murray, 2006), pp. 19-39; Paul Wilkinson, Terrorism Versus Democracy: The Liberal State Response (London: Routledge, 2011), pp. 4-21; Adrian Guelke, The Age of Terrorism and the International Political System (London: I. B. Tauris, 1998), pp. 18-34. 
key thing is to be precise (what does one mean by the word in one's own work?), to adhere rigorously to one's own chosen definition, to respect the implications of others having taken a different view, and to avoid immobilization on the mere grounds of a contested term. This current article focuses on non-state terrorism, ${ }^{7}$ while recognizing that states practise it too and that the mutual relationship between those two sets of violent acts can have historical effects of the highest significance.

A second problem often identified, but which we should perhaps consider to be of less than momentous difficulty as

${ }^{7}$ It adheres to the definition that I set out in 2009: 'Terrorism involves heterogeneous violence used or threatened with a political aim; it can involve a variety of acts, of targets, and of actors; it possesses an important psychological dimension, producing terror or fear among a directly threatened group and also a wider implied audience in the hope of maximizing political communication and achievement; it embodies the exerting and implementing of power, and the attempted redressing of power-relations; it represents a subspecies of warfare, and as such it can form part of a wider campaign of violent and non-violent attempts at political leverage' (Richard English, Terrorism: How to Respond (Oxford: Oxford University Press, 2009), p. 24). 
we move forward, is the supposed division between Critical Terrorism Studies (CTS) and Orthodox Terrorism Studies (OTS). A strong case has been made in recent years for a CTS framework, ${ }^{8}$ and there is much to applaud in the arguments and work so proffered. But I remain unpersuaded that there exists as strong a dichotomous problem in the scholarly realm here as has been suggested by some scholars.

CTS researchers have criticized OTS for its conceptual, methodological and political problems: so Orthodox scholars have (so the CTS argument runs) focused too much on non-state terrorism and not sufficiently on state terrorism; OTS academics have supposedly been too likely to endorse or legitimate state arguments and to trust state

${ }^{8}$ See Richard Jackson, Marie Breen Smyth and Jeroen Gunning (eds), Critical Terrorism Studies: A New Research Agenda (London: Routledge, 2009); Richard Jackson, Lee Jarvis, Jeroen Gunning and Marie Breen Smyth, Terrorism: A Critical Introduction (Basingstoke: Palgrave Macmillan, 2011); and also the journal, Critical Studies on Terrorism. 
sources of information too uncritically; again, as the CTS case goes, there is a need for greater theoretical sophistication of approach, a more historical and contextual approach to explanation, and a sharper focus on state terrorism.

Happily, considerable respect has existed between at least some scholars working respectively in CTS and OTS frameworks. ${ }^{9}$ But the basis for this has, ironically, been that there exists so much common ground between scholars supposedly inhabiting scholarly realms at enmity with one another. So, for example, CTS scholars' lament that OTS figures deny or ignore the existence of state terrorism would not survive scrutiny of the work of one of the founding fathers of OTS work, Paul Wilkinson. ${ }^{10}$ CTS scholars demand a critical approach by academics towards those in

${ }^{9}$ Jackson and Sinclair (2012), p. xi; Richard English and Richard Jackson (eds), 'The Belfast International Terrorism Workshop', Critical Studies on Terrorism, 2:2 (2009). 10 Wilkinson (2011), p. 17. 
state power; but this is something at the heart of the argument of Alex Schmid, whose work lies some distance from the CTS community in the latter's perception; for there does not exist a clean, neat line dividing OTS and CTS worlds, since numerous people associated with the former share some of the views supposedly typical of the latter. ${ }^{11}$ This is true also of the strong point made by some CTS scholars about the need for first-hand data (something many people not attached to CTS would themselves endorse, myself included). ${ }^{12}$ I suspect that a more accurate analysis than the dichotomous one would point to there existing a continuum of opinion between opposing poles (regarding state and/or non-state terrorism, support for or hostility towards state policies, theoretical engagements and empirical preferences, historical and regional focus, attention to first-hand sources, and so forth), along which most scholars of terrorism variously find themselves. My

11 On this, see Richards (2015), pp. 33-4, 68.

12 Richard English, Armed Struggle: The History of the IRA (London: Pan, 2012). 
intuition is that very many terrorism scholars will find themselves some distance from either extreme analytical pole here, and that there exists much agreement across the supposedly dividing line between 'Critical' and 'Orthodox' Terrorism Studies.

A third problem towards which some would point, but about which there are grounds for being reasonably relaxed, is the issue of a supposed 'stagnation' in terrorism studies. A forceful case has recently been made here by Dr Marc Sageman, a scholar whose own contributions to the field have been significant. ${ }^{13}$ In an article published in 2014, Sageman argued that:

Despite over a decade of government funding and thousands of newcomers to the field of terrorist

13 Marc Sageman, Understanding Terror Networks (Philadelphia: University of Pennsylvania Press, 2004); Marc Sageman, Leaderless Jihad: Terror Networks in the TwentyFrist Century (Philadelphia: University of Pennsylvania Press, 2008). 
research, we are no closer to answering the simple question of 'What leads a person to turn to political violence?' ... [A]fter all this funding and this flurry of publications, with each new terrorist incident we realize that we are no closer to answering our original question about what leads people to turn to political violence. The same worn-out questions are raised over and over again, and we still have no compelling answers. It seems that terrorism research is in a state of stagnation on the main issues. ... [W] still don't know what leads people to turn to political violence. ${ }^{14}$

Dr Sageman makes clear in his article that he is not reflecting on historical aspects of terrorism, or on terrorism's consequences, or on counter-terrorism. ${ }^{15}$ But in a sense this is a pity, as it makes it difficult for him then to

\footnotetext{
${ }^{14}$ Marc Sageman, 'The Stagnation in Terrorism Research', Terrorism and Political Violence, 26:4 (2014), pp. 565, 569, 576.

${ }^{15}$ Sageman (2014), p. 565.
} 
assess comprehensively what we think we know about terrorism, and how far work in the field has actually stagnated.

For, seen more fully, there has surely emerged a vast amount about which we are now considerably wiser, not least regarding why people turn to political violence. Sageman himself concedes that, 'In history, for example, there are excellent studies of previous cases of terrorism based on archival investigations, but these insights cannot be compared to present cases for lack of similar information in the present cases.' ${ }^{16}$ Perhaps so. But they surely do provide an hermeneutical framework of probability, and a guide to current problems. Indeed, here, much of what we know from our accumulated understanding of terrorism's past rather complements Dr Sageman's own arguments. When he claims, for example, that, 'There is no doubt that ideology, including global neo-jihadi ideology, is an

16 Sageman (2014), 571. 
important part of any explanation in the turn to political violence, but we still don't understand how',17 I suspect that what we know already might offer at least helpful illumination. When a significant minority of Irish men and women turned to non-state political violence during 191623, for example, ideology (republican nationalism) played its important part, but so too did the role of inter-generational conflict, the contingent leadership of particular mentors, the effect of small-group cohesive networks, the tit-for-tat escalation of anti-state violence and harsh state reaction in antiphonal sequence, the important role of incarceration as militancy developed, certain economic factors playing their part for some people, the resolution of cultural ambiguities of identity proving important for others, the appeal of revenge against enemies, the role of certain educational frameworks of motivation, the exhilaration inherent in

17 Sageman (2014), p. 567. 
militant struggle, and so forth. ${ }^{18}$ All of this fits with the evidence presented by Dr Sageman in regard to recent jihadism. Indeed, when first reading Sageman's own arguments some years ago relating to jihadist trajectories towards terroristic violence, I was struck by how familiar much of that helpfully drawn pattern actually was when set against the extensive scholarly literature on other, previous settings (such as the Irish one just mentioned).

Now, of course, to seek a pattern which is uniformly and predictively applicable across all contexts and periods in prescriptive manner would be absurd (and would lead only

18 Roy Foster, Vivid Faces: The Revolutionary Generation in Ireland 1890-1923 (London: Penguin, 2014); Richard English, Ernie 0'Malley: IRA Intellectual (Oxford: Oxford University Press, 1998); Joost Augusteijn, From Public Defiance to Guerrilla Warfare: The Experience of Ordinary Volunteers in the Irish War of Independence 1916-1921 (Blackrock: Irish Academic Press, 1996); Peter Hart, The IRA and Its Enemies: Violence and Community in Cork, 19161923 (Oxford: Oxford University Press, 1998); Peter Hart, The IRA at War 1916-1923 (Oxford: Oxford University Press, 2003); Peter Hart, Mick: The Real Michael Collins (London: Macmillan, 2005). 
to mechanistic and Procrustean and unhelpful paradigms).

But to establish a well-grounded framework within which numerous familiar patterns emerge would be of use and is entirely feasible. And we do have the basis for that already. Contrary to what Dr Sageman claims, therefore, it might be suggested that we do in fact know a considerable amount about why people turn to terrorism.

And about other elements of terrorism too. As hinted earlier, we know a lot about the conceptual issue of defining terrorism. ${ }^{19}$ Likewise, we know much in detail about the contextually located goals behind terroristic violence, involving, significantly and interwovenly: the undermining of opponents, the setting of a political agenda

${ }^{19}$ Schmid (2011); Ramsay (2015); Richards (2015); Ben Saul, Defining Terrorism in International Law (Oxford: Oxford University Press, 2006); Alex P. Schmid and Albert J. Jongman (eds), Political Terrorism (Amsterdam: North Holland Publishing, 1988); Walter Laqueur, Terrorism (London: Weidenfeld and Nicolson, 1977); David Claridge, 'State Terrorism? Applying a Definitional Model', Terrorism and Political Violence, 8:3 (1996). 
in pursuit of the redress of grievances, the provocation of an over-reaction from an enemy, the coercion of a population, the gaining of otherwise unobtainable publicity for a cause, the building of support and the sustaining of resistance, the outmanoeuvring of rivals, the securing of revenge upon enemies, and the obtaining of renown or fame or other psychologically rewarding goods. ${ }^{20}$ Relatedly, we know much about those factors which tend to lead individuals towards terrorist involvement (including important social and economic elements). ${ }^{21}$ We know a fair amount also about how and why terrorism ends, including Audrey Cronin's helpful six-fold typology, comprising: decapitation, where the leader of a group is captured or killed; terrorists' entry into legitimate political processes, with negotiation;

20 Crenshaw (2011), pp. 9-11, 34-50, 118-19, 130, 142; Richardson (2006), pp. 57-132; Guelke (1998), p. 6; Mia Bloom, Dying to Kill: The Allure of Suicide Terror (New York: Columbia University Press, 2005); Richard English, Irish Freedom: The History of Nationalism in Ireland (London: Pan Macmillan, 2006); English (2009); English (2012).

${ }^{21}$ Alan B. Krueger, What Makes a Terrorist: Economics and the Roots of Terrorism (Princeton: Princeton University Press, 2007). 
success, with the achievement of a group's aims; failure, through terrorist implosion or loss of support; crushing defeat by force and repression; and transition or reorientation from terrorist activity into other forms of violence. ${ }^{22}$ And, in all this, we know that we need to be multi-causal in our analysis of terrorist processes.

Yet again, there is a now a growing literature examining patterns of terrorist consequences, whether in terms of how far the tactic works, or in terms of the effects on its victims and on states that are attacked. ${ }^{23}$ We also know much

22 Audrey Kurth Cronin, How Terrorism Ends: Understanding the Decline and Demise of Terrorist Campaigns (Princeton: Princeton University Press, 2009); cf. Crenshaw (2011), pp. 193-222.

23 Max Abrahms, 'Why Terrorism Does Not Work', International Security, 31:2 (2006); Peter R. Neumann and Michael L. R. Smith, The Strategy of Terrorism: How it Works, and Why it Fails (London: Routledge, 2008); Javier Argomaniz and Orla Lynch (eds), Victims of Terrorism: A Comparative and Interdisciplinary Study (London: Routledge, 2015); Javier Argomaniz and Orla Lynch (eds), International Perspectives on Terrorist Victimization: An Interdisciplinary Approach (Basingstoke: Palgrave Macmillan, 2015); Conor Gearty, Liberty and Security 
about elements of appropriate best response to terrorism, not least in terms of the necessity of high-grade intelligence and the ambiguous effects of a primarily military approach. ${ }^{24}$ Finally, some organizations and individuals have become intimately understood, with layers of scholarship helping to explain their origins, dynamics and legacies in great detail. ${ }^{25}$ Moreover, it seems likely that (for

(Cambridge: Polity Press, 2013); Martha Crenshaw (ed.), Terrorism, Legitimacy, and Power: The Consequences of Political Violence (Middletown, CT: Wesleyan University Press, 1983).

${ }^{24}$ Crenshaw (2011), pp. 30, 39, 109, 178-82; Richardson (2006), pp. 243-81; English (2009); English (2015); Gary LaFree, Laura Dugan and Erin Miller, Putting Terrorism in Context: Lessons from the Global Terrorism Database (London: Routledge, 2015), pp. 221-2; Conor Gearty, Terror (London: Faber and Faber, 1991); Adam Roberts, 'Terrorism Research: Past, Present, and Future', Studies in Conflict and Terrorism, 38:1 (2015); Alex P. Schmid, 'Terrorism and Democracy', Terrorism and Political Violence, 4:2 (1992).

25 Bruce Hoffman, Anonymous Soldiers: The Struggle for Israel, 1917-1947 (New York: Alfred A. Knopf, 2015); Bruce Hoffman and Fernando Reinares (eds), The Evolution of the Global Terrorist Threat: From 9/11 to Osama bin Laden's Death (New York: Columbia University Press, 2014); Manoj Joshi, 'On the Razor's Edge: The Liberation Tigers of Tamil Eelam', Studies in Conflict and Terrorism, 19:1 (1996); 
all the talk of new and different kinds of terrorism), what we know from our cumulative research over the years remains highly relevant even as contemporary terrorism - like other social phenomena - evolves. ${ }^{26}$

Rashmi Singh, Hamas and Suicide Terrorism: Multi-Causal and Multi-Level Approaches (London: Routledge, 2011); Carl A. Wege, 'Hizbollah Organization', Studies in Conflict and Terrorism, 17:2 (1994); English (2012); Robert P. Clark, The Basque Insurgents: ETA, 1952-1980 (Madison: University of Wisconsin Press, 1984); Stefan Aust, Baader-Meinhof: The Inside Story of the RAF (New York: Oxford University Press, 2009); Martha Crenshaw Hutchinson, Revolutionary Terrorism: The FLN in Algeria, 1954-1962 (Stanford: Hoover Institution, 1978); Michael Scheuer, Osama bin Laden (Oxford: Oxford University Press, 2011); Andrew Silke, 'Rebel's Dilemma: The Changing Relationship between the IRA, Sinn Fein and Paramilitary Vigilantism in Northern Ireland', Terrorism and Political Violence, 11:1 (1999); Khaled Hroub, Hamas: Political Thought and Practice (Washington: Institute for Palestine Studies, 2000); Henry McDonald and Jack Holland, INLA: Deadly Divisions (Dublin: Poolbeg Press, 1994); Joseba Zulaika, Basque Violence: Metaphor and Sacrament (Reno: University of Nevada Press, 1988); Cato Hemmingby and Tore Bjorgo, The Dynamics of a Terrorist Targeting Process: Anders B. Breivik and the 22 July Attacks in Norway (Basingstoke: Palgrave Macmillan, 2016); Angus M. Muir, 'Terrorism and Weapons of Mass Destruction: The Case of Aum Shinrikyo', Studies in Conflict and Terrorism, 22:1 (1999).

${ }^{26}$ Crenshaw (2011), pp. 51-66. 
If definition, the CTS/OTS division, and research stagnation are not our main problems as we face into the next phase of academic work on terrorism, then what should concern us more? Centrally, the problem we face is the post-9/11 emergence of a more markedly disjointed body of scholarship, divided along five continua, at the rival ends of which are positions which do reflect potentially unhelpful dichotomies and disjunctions.

The first dichotomy is that between those exhibiting a pre9/11 and those exhibiting a post-9/11 commencement of engagement in terrorism research; the second is between non-US-based, and US-based scholars; the third is between those who focus on case-study, particularistic analysis, and those favouring more wide-angled and nomothetic (often metrics-based) work; the fourth is the division between 
field-based and distant analysis; and the fifth is between those who see terrorism primarily as a symptom of more important phenomena, and those who consider it to be the issue in itself.

My argument is not that one end of any of these continua is preferable to the other; we need work which has all of these inclinations. The problem is that, at present, it is far from clear that scholars who work close to or at one end of one of these continua engage sufficiently with the work of those towards or at the opposite end; there is a danger that as a community of scholars we suffer myopia as a consequence.

It is widely recognized that there has been a vast explosion of research on terrorism in the wake of (and prompted by the attacks on) $9 / 11 .{ }^{27}$ In addition, therefore, to the

27 Jackson and Sinclair (2012), p. 1. 
incredibly valuable work of pre-9/11 pioneers, ${ }^{28}$ there emerged a new wave of scholarship from equally impressive scholars, some of whose analysis drew excitingly on a diverse range of disciplines and offered pioneeringly brilliant insights. ${ }^{29}$

So it is true for many people, as one recent set of authors has phrased it, that 'much of our thinking about terrorism, right down to basic assumptions about who commits terrorism, what terrorism is, where it occurs, how often it happens, why it happens, and what governments can do about it have been shaped for the past decade in large part by the

${ }^{28}$ For example, Martha Crenshaw, Bruce Hoffman, Adrian Guelke, Alex Schmid, Conor Gearty, Charles Townshend, Paul Wilkinson, Ariel Merari, Mark Juergensmeyer, David Rapoport, Andrew Silke.

${ }^{29}$ See, for example, Jacob N. Shapiro, The Terrorist's Dilemma: Managing Violent Covert Organizations (Princeton: Princeton University Press, 2013); Eli Berman, Radical, Religious and Violent: The New Economics of Terrorism (Cambridge: MIT Press, 2009); LaFree, Dugan and Miller (2015); Robert A. Pape, Dying to Win: Why Suicide Terrorists Do It (London: Gibson Square Books, 2006). 
enormous shadow cast by $9 / 11^{\prime} .^{30}$ And there is sometimes a tendency to read post-9/11 terrorism as embodying something which fundamentally differs from what went before (a view significantly challenged, however, by some of the more authoritative scholars whose research long predated 11 September). ${ }^{31}$

My own sense is that the evolution of terrorism is such that there is always likely to be fluidity, with change coexisting with considerable continuity. The challenge, when a major scholarly fault-line appears, is for those on either side to engage with each other's work creatively and fruitfully. As things stand with the $9 / 11$ divide in academic work, it is unclear that this has worked well in either direction. How much of the more recently produced work have longerrooted scholars managed to engage with positively, for

30 LaFree, Dugan and Miller (2015), p. 2.

31 See, for example, Crenshaw (2011). 
example? And does post-9/11 work draw as far as it should on pre-9/11 research?

Let's take one very strong example of post-9/11 engagement, the work of Professor Gary LaFree and his colleagues. In an excellent book dealing with the important work of the Global Terrorism Database (GTD), LaFree, Dugan and Miller include in their chapter bibliographies: 162 references to material published in 2002 or afterwards, and 86 references to items published during the much longer period up to and including 2001.32 Now, this is a fine book; and it might be judged that, since there has been so much work on terrorism published after 2001, these proportions are about right. But it is perhaps worth noting some of the work not referred to in this book: nothing from Paul Wilkinson, for example, nor Ariel Merari, Adrian

32 LaFree, Dugan and Miller (2015), pp. 10-11, 25-6, 48, 69, 95-8, 124, 145, 172, 202-4, 223-5. 
Guelke, Conor Gearty, Mark Juergensmeyer (and only one reference to work by Alex Schmid).

As suggested, it is also important to ask how far pre-9/11 scholars (who in many cases have presumably a continuing interest in the subject after that 2001 atrocity) engage humbly and enhancingly enough with the new waves of work post-9/11, and with the newly emerging database resources now available.

This problem combines with our second issue, the tension between non-US-based and US-based scholars in the field. The striking expansion of US academic interest in terrorism after the $9 / 11$ atrocity has brought with it very many huge advantages, with scholars of very high ability now deservedly prominent in the field (including some, of course, who had a record of terrorism scholarship before $9 / 11$ as 
well). ${ }^{33}$ The non-US-based list of scholars is equally impressive. ${ }^{34}$ US scholarship has often tended to be determined by a focus on 9/11-related terrorism and on anti-US threats, whether involving al-Qaida, or other violence in the conflicts in Afghanistan and Iraq that were justified as counter-terrorism against jihadist enemies. Has the shadow of $9 / 11$ been as significant in non-US scholarly contexts? Less so, I think, and the statement by LaFree, Dugan and Miller - that, 'It is hard to imagine starting a book about terrorism in the early twenty-first century that does not begin by referring to $9 / 11^{\prime 35}$ - not only seems less persuasive when read from Western Europe, but also raises

33 Such scholars include Daniel Byman, Eli Berman, Bruce Hoffman, Martha Crenshaw, Mark Juergensmeyer, Dipak Gupta, John Horgan, Max Abrahms, Barbara Walter, Mia Bloom, David Rapoport, Alan Krueger, Laura Donohue, Joseba Zulaika, Jacob Shapiro, Robert Pape, David Laitin, Barak Mendelsohn.

${ }^{34}$ Among others: Alex Schmid, Javier Argomaniz, Anthony Richards, Andrew Silke, Gilbert Ramsay, Richard Jackson, Ariel Merari, Rashmi Singh, Claude Berrebi, Diego Muro, Esteban Klor, Stuart Croft, Conor Gearty, Adrian Guelke, Thomas Hegghammer, Donatella Della Porta, Tore Bjorgo, Rogelio Alonso, Fernando Reinares, Diego Gambetta.

${ }^{35}$ LaFree, Dugan and Miller (2015), p. 7. 
one problem which those authors themselves wisely note: namely, that $9 / 11$ was very much an outlier within the world of terrorism (certainly in terms of the number of fatalities caused, and the international complexion to the attack). So to read much of our assessment of terrorism through the lens of this particular assault would be a mistake. The question here is how far these two sets of scholars have been developing bibliographies respectively too innocent of one other.

The third continuum - running from the case-studyoriented and the particularizing at one end, to the nomothetic and more wide-angled approach at the other has also involved something of a dichotomy between those whose work has been largely non-numerical, and those whose scholarship has been founded on metrics, statistics and database-grounded empiricism. As with the previous two dichotomies, my intuition here is that the profound insights available from the rival hermeneutical approaches 
have not been as fully respected by the alternative school in each case as would be ideal.

On the metrics, let's again briefly consider that superb example of database scholarship, the Global Terrorism Database maintained so impressively by the START team at the University of Maryland. There can be little doubt about the immense value of this endeavour, and I choose this case precisely because it is such a positive one. As noted, the Director of the National Consortium for the Study of Terrorism and Responses to Terrorism (START), Professor Gary LaFree, has been admirably lucid about how far 9/11 was an extremely unusual and atypical terrorist attack, and he and his co-authors have stressed the need therefore to set such an attack in proper context within the wider universe of terrorism. In doing so, LaFree and his colleagues have identified some key themes within this broader world, drawing strongly on the GTD data. So terrorism turns out to tend to be mostly launched against local targets, to be 
concentrated in a comparatively small number of locations, to involve in many cases few or even no fatalities, and often to be carried out by perpetrators whose identity it is difficult to determine. ${ }^{36}$

Now one hermeneutical question to ask here - whether one works in a database-grounded world or not - is what can be gleaned from this GTD approach that cannot be arrived at by case-study work in each particular setting? In other words, what can a database allow you uniquely to do? Since the GTD scholars rightly stress that within their broader patterns one needs still to appreciate varied context, the real question here seems this: what can you only know about (say) Basque terrorism in the 1970s and 1980s by reading it through GTD lenses, that you could not know through detailed, case-study analysis of the Basque case and its direct connections elsewhere (such as the US diaspora)? If we learn little uniquely from the GTD about, say, causation,

${ }^{36}$ LaFree, Dugan and Miller (2015). 
consequences, and the efficacy of different kinds of state response in a specific case such as this, then what is the value in the GTD?

Now it seems to me that there can indeed be very serious goods presented by databases. Professor LaFree and his colleagues' emphasis that we should not bias our assessment of or response to terrorism through overfocusing on 9/11, when the universe of terrorist cases shows $9 / 11$ to be very unusual, provides a powerful example. Another illustration might be that such comprehensive, wide-angled approaches might force us to ask new kinds of question, less visible to the case-study scholar with eyes only for one setting. If, for example, it turns out that the most usual pattern is for terrorists to be slightly wealthier than is typical in their community, but that this was not the case in Northern Ireland, ${ }^{37}$ then a statistical approach can force us to ask exciting questions about why

37 Krueger (2007), pp. 44-6. 
this was the case (questions which a scholar of Northern Ireland alone might not have asked).

Looking in the other direction, the case-study specialist needs to be aware both of how their work relates to wider patterns, and of what can uniquely be seen through their own detailed approach towards one context. So, to take our Basque illustration again, it seems to me that ultimately the causes, consequences, dynamics and probably the endings of Basque separatist violence will only fully be understood if one immerses oneself in a wealth of primary and other sources relating to closely-viewed behaviours and politics over many years in the Basque and Spanish regions.

I think that the challenges at both ends of this continuum are sharper than tends to be recognized (since people tend mostly to do what they methodologically do, and to speak with people who do likewise). But if we are to gain maximum insight into the grand subject that we are 
addressing over the next fifty years of terrorism research, then we need to push ourselves hard regarding what our respective methodologies uniquely achieve. If we return to the GTD, then much that is stressed on the basis of these data would be known in each context to students of, for example, the Baader-Meinhof Group, the PLO, Hamas, ETA, the IRA, the UDA, FARC and so forth. If, for example, the GTD suggests the likelihood (but not the certainty) that terrorism will be concentrated in certain settings, that it will involve largely orthodox weapons, that it will involve a pattern of locality (the bomber originating near where their bomb exploded), students of all of the above groups would know this already in regard to their own case. And if we are to draw wider patterns, then we need to be sure what value that offers and also that we are actually on solid ground with our database data. To say that terrorism globally rose from the early 1970s until the early 1990s, dipped till after 2001, then rose again, is of little use if one if responding to concentrated, localized terrorism in (say) Israel. There, one 
needs to know whether and why levels of terrorism have varied in that specific setting. Terrorism doesn't happen in general; it happens in specific places at specific times to specific and unique people.

None of this is to lessen the importance of databases. Indeed, my sense is that instinctively case-study-oriented scholars such as myself need to do more to engage with the riches available from the GTD and other such sources. But the present reality is that most people working at either end of this continuum feel uncomfortable about the approaches at the other end, and conveniently ignore them more than would be helpful. I suspect that the study of terrorism is not unique in experiencing this problem, since related areas of study have likewise prompted divergent methods and approaches. $^{38}$

${ }^{38} \mathrm{On}$ peace and peacekeeping, for example, see V. Page Fortna, Does Peacekeeping Work? Shaping Belligerents' Choices After Civil War (Princeton: Princeton University Press, 2008); cf. the very different approach evident in 
My fourth continuum stretches from those whose work is essentially field-based (grounded in residence in or lengthy immersion in the setting of the violence itself) as against those whose work is largely produced in settings some distance away. Again, it is not that one kind of work is preferable to the other. I think that brilliant scholarship can emerge from people who have been largely embedded in the field (Ariel Merari, Adrian Guelke, Claude Berrebi) and also from those whose working life has existed at some long remove from the violence almost all of the time (Robert Pape, Max Abrahms, Barbara Walter). And again this is not just the case with the study of terrorism, and it includes an important distinction even for those distant scholars who do make some visits to the field. So Page Fortna's impressively

Oliver P. Richmond and Jason Franks, Liberal Peace Transitions: Between Statebuilding and Peacebuilding (Edinburgh: Edinburgh University Press, 2009), and Roger MacGinty, No War, No Peace: The Rejuvenation of Stalled Peace Processes and Peace Accords (Basingstoke: Palgrave Macmillan, 2006). 
systematic study of the efficacy of peacekeeping, for instance, involved valuable fieldwork-based interviews to complement its quantitative analysis. But these interviews were, in each instance, carried out over what appear to have been very short in-country sojourns: in Bangladesh, January 2002; Sierra Leone, November 2002; and Mozambique, December 2002.39

Finally, I think an important distinction can be drawn between those who see terrorism as fundamentally a symptom of, or a lens through which to read, other and more important phenomena, and those whose focus is overwhelmingly on the issue of terrorism as the thing in itself. This is a more difficult distinction to draw, since when pushed - most people will say that, of course, other matters are crucial. But it seems to me that most of us who work on terrorism incline more either to the view that, in doing so, we need to think equally sustainedly about

${ }^{39}$ Fortna (2008), pp. 202-5. 
nationalism, about religion, about the economy, about the state, as we do about terrorism; and those of us who think that most, if not all, of our research and writing can be effective without reading more than cursorily in each of those other subjects. So those scholars whose bibliographies (and publications) attend significantly to delving into related but arguably larger phenomena (Timothy Wilson?), do seem to me profoundly different in emphasis from those whose work and reading focus much more exclusively on terrorism itself (Rohan Gunaratna?). An important aspect of this involves also the overlap between different kinds and levels of violence, including the painful intersection of terrorism with civil war. ${ }^{40}$

This adumbration of five continua is necessarily too brief to prove its case definitively. My aim is rather to prompt a

40 Stathis N. Kalyvas, 'The Paradox of Terrorism in Civil War', Journal of Ethics, 8 (2004); V. Page Fortna, 'Do Terrorists Win? Rebels' Use of Terrorism and Civil War Outcomes', International Organization, 69:3 (2015). 
debate about how best we can all collaborate in order to study this important topic in coming decades. But it does seem to me both that these continua exist (think of the last thirty books that you have read on terrorism, and something of this map will become evident, I suggest), and also that a failure to ensure proper dialogue along these continua will damage our collective efforts in the future.

For there is also something of a clustering at each end. Post9/11 scholars, based in the United States of America, focused on wide-angled and metrics-based methodology, working at a distance from the violence that they study, and treating terrorism as the key issue to be analysed attendance at US Conferences and Symposia and Seminars on terrorism in the past fifteen years will provide plenty of evidence of such scholars (many of them truly superb). NonUS-based scholars, who worked on terrorism before 9/11, whose emphasis is more case-study analytical and qualitative in approach, who are more likely to work close to 
the violence that they study, and whose arguments often tend towards an emphasis on related phenomena experience of Western European work, for example, again yields many names.

As with all such models, there is simplification here, I admit. But I think that these points are important. They relate to multi-disciplinary practice (which everyone in principle applauds, but in practice finds it much more difficult to achieve); and also to a deeper geographical problem too. Put starkly, the vast majority of researchers working on terrorism live and work in places where there exists comparatively little terrorism, while those places where terrorism tends to be most concentrated are ones from which very little terrorism scholarship is drawn.

This seems to me an absolutely vital point. A third of all terrorist attacks recorded in the GTD have occurred in just five countries: Colombia, India, Iraq, Pakistan, Peru; in 
2012, over half of all worldwide terrorist attacks occurred in just three countries: Iraq, Pakistan, Afghanistan. ${ }^{41}$ Now let's consider (as a suggestive illustration of my point) the wellestablished and rightly well-regarded journal Terrorism and Political Violence (TPV). And I select this example because it is a major journal, one which I greatly respect, and one with which I have had the privilege of having some editorial involvement - so I am in no way choosing a journal at which I am levelling criticism or hostility. For the years 2000-14, if one examines the online version of the journal and lists the University affiliations or places of work given for authors of substantive pieces, then the following numbers of author locations emerge: USA 281; UK (excluding Northern Ireland) 82; Northern Ireland 27; Israel 50; Spain 24; Canada 22; Sweden 15; Australia 13; Germany 11; Holland 8; Norway 8; Turkey 8; Denmark 5; Singapore 5; Czech Republic 4; Republic of Ireland 4; Belgium 3; Colombia 3; Finland 3; India 3; Lebanon 3; New Zealand 3; Russia 3;

${ }^{41}$ LaFree, Dugan and Miller (2015), p. 53. 
Austria 2; China 2; France 2; Italy 2; South Africa 2; Switzerland 2; and 1 each for Brazil, Chile, Eqypt, Greece, Hong Kong, Iraq, Italy, Japan, Mexico, Poland, Portugal, Qatar, Samaria, Sri Lanka, Sudan. From a total of 615 author locations during 2000-14, therefore, 281 (46\%) originated from US-based scholars; and 440 (71.5\%) originated from the USA, UK and Israel between them.

As I say, there is no criticism levelled here at the journal. It's an English-language forum, and in any case editors can only select from the articles that are submitted to them; so the weightings evident here merely reflect the contextual problem that I am identifying. But, if we do think that one distinctive set of insights (among many) can be provided by terrorism scholars working long-term in settings which allow for intimacy of understanding, for deep knowledge of local nuance, personnel, history, cultural change and detail, then it might seem regrettable that (for example) only 7 out of 615 author locations from this entire period (a mere 1\%) 
involved people based in any of the five countries which account for a third of all GTD terrorist attacks: Colombia (3), India (3), Iraq (1), Pakistan (0), Peru (0).

Of course, as noted, superb research is done by people resident in places experiencing little terrorism. Moreover, it's true that some countries which have experienced lengthy and endemic terrorism are represented strongly in this list of author locations mentioned above (Israel, Spain, Northern Ireland). Even here, however, during the 2000-14 period both the Spanish and Northern Irish levels of violence had significantly decreased from those of earlier decades (thankfully).

In any case, my point is not to reproach journal editors or anyone else about this issue. It is simply to identify something rarely mentioned in our field: that there is surely a major potential source of contextualized knowledge, wisdom, intuition, understanding and detailed insight 
available to us, which we currently lack on the basis of such a pattern. Moreover, I suspect that this TPV case is not unique. If you are reading this article in a University setting in the USA, UK, Israel, Spain, Canada, Sweden, Australia or Germany, then ask yourself how many of the visiting speakers who lectured on terrorism at your institution over the past five years were people who were then working as scholars based in Colombia, India, Iraq, Pakistan or Peru. If you are in your study or the relevant part of your Library as you read this, then look at the bibliographies contained in thirty influential books on terrorism on your shelves, to see how many of the items listed there were produced by people long resident in places marked by endemic terrorism, and which thus gave access to lengthily acquired intimacy of understanding on that basis. This issue is especially vital because it is precisely in those societies in which terrorism becomes endemic (even epidemic) in nature, that we most require scholarly understanding and explanation and response. 
What is to be done? It seems to me that there is a profound need for all of us wanting to understand terrorism to read across these five continua more than we tend to do; to select the most excellent versions of the kind of work and emphasis with which we are least sympathetic and to engage directly with it; to reflect this kind of inclusive approach in our teaching (the next generation of scholars being more important for the process addressed in this article than is the current one); and to be prepared not only to debate along the full lines of these continua, but also to organize how we work in tune with such an approach too.

On the last point, this would involve some hard questions about how we organize our respective Seminar and Lecture series at universities; how we run and how flexibly we 
approach journals in the field; and even how we plan to organize and administer (and appoint people to) university departments, schools, institutes and centres.

There is an understandable tendency to work within narrow parameters (reading fully even in one sub-disciplinary specialism is a heavy burden; to read beyond this is more taxing still). But what we should be aiming for in the next fifty years is not a series of separately defined, mutually deaf mini-communities of scholars, but rather that we collectively learn what can decisively be learned, and move the debate forward for everybody.

Some of this is comparatively easy. If I may be forgiven briefly praising my own colleagues at the University of St Andrews: the people working at the Handa Centre for the Study of Terrorism and Political Violence in recent years have been drawn from many disciplinary backgrounds (Political Science, International Relations, History, 
Psychology, Anthropology among them). And our invited speaker series has featured people with a pre-9/11 interest as well as those who have come to the subject more recently; people based in the US and people based elsewhere; case study and field-based scholars, and nomothetic and more distantly based ones too; people focusing on terrorism as such, and people whose careers have been devoted mainly to addressing related phenomena. (The CSTPV web site gives details.) My point is certainly not that St Andrews gets things right. But it is true that staff and students at the university have gained hugely from these diverse insights being drawn upon in their ongoing work on terrorism.

The implications of this are significant also for our publications and our databases. To harmonize the different approaches of the metrics-based and the case-studyoriented might enrich both approaches. To take the best of the databases again, the GTD: if one were more fully to marry the methods of the START team with those of field- 
based, case-study analysts, there would probably emerge an even more rich database on which we could all work. I suspect, to take one example, that the GTD figures for terrorist attacks in the early 1970s significantly underestimate the genuine total; ${ }^{42}$ so the overall judgment of Professor LaFree and his colleagues, that there occurred 'a steady increase' in terrorism between the early 1970s and the start of the $1990 \mathrm{~s},{ }^{43}$ might itself require reconsideration, using a wider range of the available sources and expertise than are currently adduced for use in the GTD. Professor LaFree and colleagues acknowledge that they have probably undercounted early-1970s numbers, ${ }^{44}$ and the challenge for all of us here is to engage creatively so that the richest sources and expertise can produce the best possible data.

42 LaFree, Dugan and Miller (2015) suggest a global figure for terrorist attacks for 1972 at well under 1000 (p. 29). Since the respected Conflict Archive on the Internet (CAIN) records well over 10,000 shooting incidents and well over 1000 bomb explosions in Northern Ireland alone for 1972, that figure seems implausible.

${ }^{43}$ LaFree, Dugan and Miller (2015), p. 27.

${ }^{44}$ LaFree, Dugan and Miller (2015), p. 33. 
And case-study experts need, more frequently than has been typical, to draw on the rich rewards that can be found in sources such as the GTD. If, for example, a case study is something of an outlier, then important questions about that case study are generated. Was this atypicality inevitable (in which case, what were the structural factors making it so?); or was this atypicality avoidable (in which case, what were the contingent factors deciding its actual trajectory?). If more case study analyses addressed these questions (questions which can cast light on wider patterns), then they would be rendered more significant. We need proper dialogue between the nomothetically inclined and the casestudy obsessed.

Likewise: if the GTD suggests that most terrorist groups exist for only a short period, while a smaller but far more 
lethal set of organizations persists for longer periods, ${ }^{45}$ then again questions are raised for idiographically as well as nomothetically inclined scholars. Are there patterns determining behaviour predictably across cases, or is this a world of jaggedly messy and unpredictable contingency? Either way, there is work to be done to find out (and scholars like myself whose inclinations lie more with the idiographic approach need to do more to engage with these wider questions about cross-case comparisons and patterns and echoes or differences). It is no accident that much of the best work on political violence has emerged from those scholars who do most impressively combine wide-angled, nomothetic analysis with case-study specificity. ${ }^{46}$

${ }^{45}$ LaFree, Dugan and Miller (2015), p. 81.

${ }^{46}$ Stathis N. Kalyvas, The Logic of Violence in Civil War (Cambridge: Cambridge University Press, 2006); Paul Staniland, Networks of Rebellion: Explaining Insurgent Cohesion and Collapse (Ithaca: Cornell University Press, 2014); Jeremy M. Weinstein, Inside Rebellion: The Politics of Insurgent Violence (Cambridge: Cambridge University Press, 2007); Hemmingby and Bjorgo (2016); Shapiro (2013); Berman (2009). 
Wider reading, and attention to the linkages between our understanding of terrorism and of other major phenomena, are important in other ways too. So if one celebrates the legacy of the long-eighteenth-century European Enlightenment (in terms of a belief in rationality, progress, self-improvement, cosmopolitanism, liberal democracy and a secular understanding of human nature), ${ }^{47}$ then this will unavoidably involve our taking a certain (contingent, and largely hostile) stance in our analysis of jihadist groups such as al-Qaida and ISIS. Recognizing the partiality and contingency of that stance is important, and it emphasizes why the study of terrorism is, as so often, about far more than mere terrorist violence.

And sometimes, what we know about terrorism and how to respond to it can only be seen most clearly if we do read along continua and across disciplines and beyond a

${ }^{47}$ Anthony Pagden, The Enlightenment and Why It Still Matters (Oxford: Oxford University Press, 2013). 
narrowly defined field of work. There has recently been something of an eirenic turn in the wider scholarly literature relevant to terrorism and counter-terrorism; but this is only properly visible if one reads well beyond the terrorism studies literature itself, and if one digs deeply into diverse disciplines. So Jonathan Sacks' Biblically-grounded, theological argument (that proper understanding of the roots of violence and of the relationships between religious faiths points towards harmony, empathy and shared humanity rather than towards violent conflict), might be seen to reinforce psychologist Steven Pinker's claim that humanity is growing less, rather than more, violent over time; the arguments of both scholars are further complemented from other disciplines again by the work of people such as Erica Chenoweth, Maria Stephan, Adam Roberts and Timothy Garton Ash, with their suggestion that civil resistance rather than violence has offered the most effective way of producing political change. To this might be added historian David Cannadine's erudite argument that 
when we carefully survey identities relating to religion, nation, class, gender, race and civilization - and do so historically - we find evidence of shared humanity rather than of antagonistic enmity across binary divisions. Yet again, we might adduce psychologist Simon Baron-Cohen's argument that a full understanding of empathy provides us with a deep resource in the pursuit of conflict resolution, if we choose to deploy it; or also neuroscientist Shane O'Mara's strong argument that there are very clear scientific explanations for torture not working (with all that that implies for the policies of many state and non-state adversaries). ${ }^{48}$

48 Jonathan Sacks, Not in God's Name: Confronting Religious Violence (London: Hodder and Stoughton, 2015); Steven Pinker, The Better Angels of Our Nature: The Decline of Violence in History and its Causes (London: Penguin, 2011); Erica Chenoweth and Maria J. Stephan, Why Civil Resistance Works: The Strategic Logic of Nonviolent Conflict (New York: Columbia University Press, 2011); Adam Roberts and Timothy Garton Ash (eds), Civil Resistance and Power Politics: The Experience of Non-Violent Action from Gandhi to the Present (Oxford: Oxford University Press, 2009); David Cannadine, The Undivided Past: History Beyond Our Differences (London: Penguin, 2013); Simon Baron-Cohen, 
None of these works lies centrally within the terrorism studies realm; but each of them individually, and all of them collectively, highlight a very important set of insights for our understanding of the dynamics and context of, for example, twenty-first-century suicide terrorism and responses to such terrorism. The point is this: in order to see this scholarly insight properly, we do have to read across methodological boundaries and, equally importantly, to address the problem that some people still too narrowly define the boundaries around the study of terrorism (and discuss terrorism research as if it occurs overwhelmingly in a very small set of journals and titles). Much of the very best work on terrorist violence and terrorist actors is not published in terrorism studies journals, or in books with 'terrorism' in the title. Instead, it addresses the contextually,

Zero Degrees of Empathy: a New Theory of Human Cruelty and Kindness (London: Penguin, 2012); Shane O'Mara, Why Torture Doesn't Work: The Neuroscience of Interrogation (Cambridge: Harvard University Press, 2015). 
historically, culturally located emergence and dynamics of political violence which many would consider to be terrorism. ${ }^{49}$ To ignore this wider literature limits the profundity and accuracy of the conclusions that can be reached.

Conclusion

This article is intended to prompt debate and reflection, rather to claim that its author possesses ultimate answers or solutions. But it does seem to me that, across the broad questions of definition, causation, consequences and response (after all, the main subjects to address in relation to terrorism), we have some very strong foundations on

${ }^{49}$ For important examples among very many, see Charles Townshend, Political Violence in Ireland: Government and Resistance Since 1848 (Oxford: Oxford University Press, 1983); Charles Townshend, The Republic: The Fight for Irish Independence (London: Penguin, 2013); Zulaika (1988); Clark (1984); Aust (2009). 
which to build, given the frequently excellent work of the past fifty years. We should respect those. But we should aim to ensure that we produce a less fragmented and more self-consciously inclusive and collective way of working if the next phase of our work is to reach the highest standards.

For this work not only offers academically significant research into a major phenomenon; it also possesses heavily practical consequences. Both the twentieth and the twentyfirst centuries began with a terrorist attack, state responses to which altered the course of history very bloodily indeed. Nobody in the academic community will be foolish enough to think that our insights will directly or mechanically govern political decisions (and nor should they). But a failure to move forward as a scholarly community and to try to build inclusive insights and to develop them together, will have potential effects in terms of limiting policy-relevant debate. What we need is simultaneously to consider terrorism, counter-terrorism, and the relationship between them, and to do so in truly multi-disciplinary manner with 
an eye to policy seriousness. ${ }^{50}$ This article has sought to provoke debate about how best - in practice - we might move that important work forward.

Word count: 9220

${ }^{50}$ English (ed.) (2015). 